\title{
Multiple Gastrointestinal Stromal Tumors of the Duodenum Associated with Neurofibromatosis Type
}

\author{
Shigenaga Matsui*, Hiroshi Kashida, Kenji Nomura, Yoriaki Komeda and Masatoshi Kudo \\ Department of Gastroenterology and Hepatology, Kindai University Faculty of Medicine, Japan
}

Submission: December 31, 2019; Published: January 07, 2020

*Corresponding author: Shigenaga Matsui, Department of Gastroenterology and Hepatology, Kindai University Faculty of medicine, Osaka, Japan

\begin{abstract}
A 69-year-old woman patient, with known neurofibromatosis type 1(NF1), was admitted to our hospital for melena. Gastrointestinal endoscopy revealed several submucosal tumors with ulcer in the second of the duodenum. The patient underwent subtotal stomachpreserving pancreaticoduodenectomy (SSPPD). Those tumors were diagnosed gastrointestinal stromal tumors (GISTs) in the duodenum with NF1-related.

Keywords: Neurofibromatosis type 1; Von Recklinghausen's disease; Gastrointestinal stromal tumors; Duodenum

Abbreviations: NF1: Neurofibromatosis Type 1; VRD: Von Recklinghausen's Disease; GISTs: Gastrointestinal Stromal Tumors; CT: Computed Tomography; EUS: Endoscopic Ultrasound; SSPPD: Subtotal Stomach-Preserving Pancreaticoduodenectomy; PDGFRA: Platelet-Derive Growth Factor Receptor A polypeptide
\end{abstract}

\section{Introduction}

Neurofibromatosis Type 1(NF1), also known as Von Recklinghausen's Disease (VRD), is a hereditary autosomal dominant disease with an incidence rate of from $1 / 2,000$ to $1 / 5,000$ in most population base studies [1]. NF1 is a dominantly inheritable disease with abnormality at chromosome 17q11.2, which leads to a loss of neurofibromin, a tumor suppressor protein $[1,2]$. Therefore, patients with NF1 have a higher risk of developing various malignant neoplasms, with Gastrointestinal Stromal Tumors (GISTs) developing in approximately 5-25\% of patients with NF1 [3]. We report a case of the multiple GISTs of the duodenum associated with NF1.
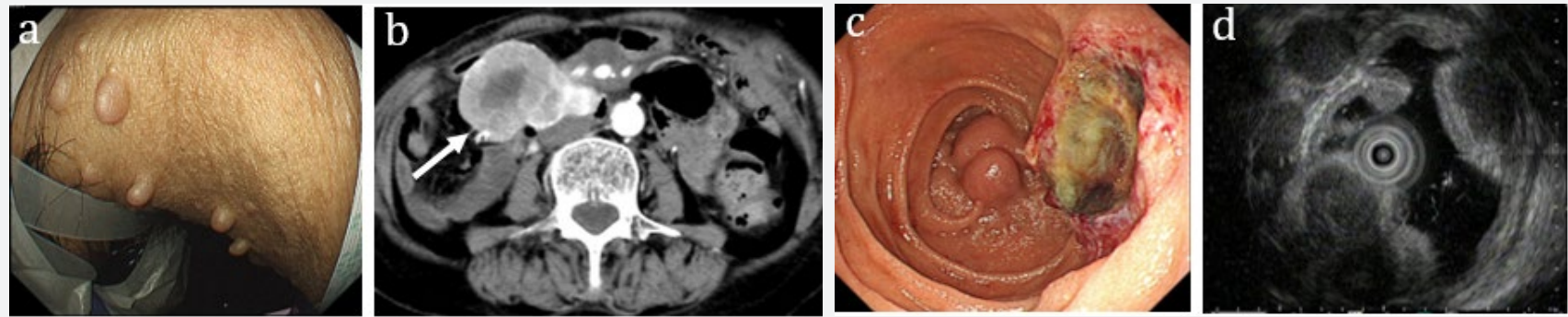

Figure 1: Diffuse cutaneous multiple neurofibromas on the skin (a). Abdominal computed tomography (CT) revealed tumors (arrow) with contrast effect in the second of the duodenum (b). Gastrointestinal endoscopy revealed several submucosal tumors with ulcer in the second of the duodenum (c). Endoscopic ultrasound revealed multiple low echoic masses from the muscle layer (d). 


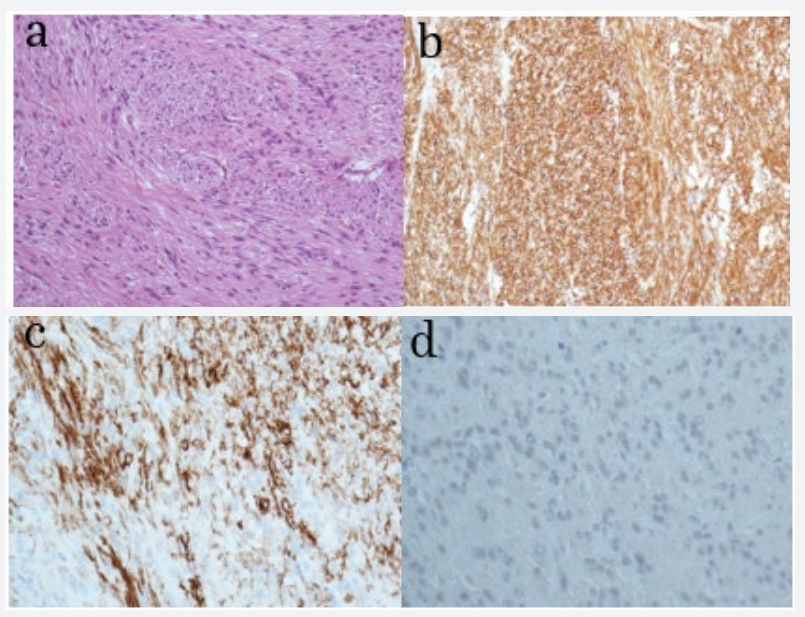

Figure 2: Pathological examination (HE staining $\times 200$ ) of the tumors revealed the fascicular proliferation of spindle-shaped cells $(a)$. Immunohistochemical staining revealed that the tumor cells were positive for c-kit (b), CD34 (c), and for negative desmin (d).

A 69-year-old woman patient, with known NF1, was admitted to our hospital for melena the physical examination revealed diffuse cutaneous multiple neurofibromas on the skin (Figure 1a). Abdominal Computed Tomography (CT) revealed tumors with contrast effect in the second of the duodenum (Figure 1b). Gastrointestinal endoscopy revealed several submucosal tumors with ulcer in the second of the duodenum (Figure 1c). Endoscopic Ultrasound (EUS) revealed multiple low echoic masses with clear boundary derived from the muscle layer (Figure 1d), suggesting the diagnosis of GISTs. The patient subsequently underwent Subtotal Stomach-Preserving Pancreaticoduodenectomy (SSPPD). Pathological examination (Hematoxylin and Eosin staining) of the tumors revealed the fascicular proliferation of spindleshaped cells, predominantly in the muscle layer (Figure. 2a). Immunohistochemical staining revealed that the tumor cells were positive for c-kit and CD34(Figure. 2b \& 2c), but the cells were negative for S-100 and desmin (Figure. 2d). Thus, those tumors were confirmed GISTs in the duodenum with NF1.

\section{Discussion}

NF1 should be suspected in the presence of multiple cutaneous neurofibromas, café au lait spots, axillary or inguinal freckling [4]. It is a dominantly inheritable disease with abnormality at chromosome 17q11.2 [1,2]. This gene encodes a GTPase activating protein which can regulate the activity of the p21 product of the ras oncogene, and which seems to play an important role in controlling cellular proliferation and differentiation in a wide range of tissues. Different gene mutations are involved in the development of the various clinical manifestations of NF1, including malignant tumors, with GISTs [5]. Therefore, GISTs is reported developing in approximately $5-25 \%$ of patients with NF1 [3].
GISTs are the most common mesenchymal neoplasms of the gastrointestinal tract, originating from the progenitors of intestinal cells of Cajal, which regulate digestive tract motility [6]. Sporadic GIST has been considered to involve specific KIT (CD117) or Platelet-Derive Growth Factor Receptor $\alpha$ Polypeptide (PDGFRA) signaling - driven tumors, KIT and PDGFRA activating mutations are the oncogenic mechanisms in most sporadic GISTs. In NF1-related GIST, mutation in KIT and PDGFRA are rarely found [7-9]. Sporadic GIST can occur within the entire gastrointestinal tract, in which it accounts for the largest proportion of $60-70 \%$ in the stomach, $25-30 \%$ in the ileum to jejunum, $5-15 \%$ in the colorectum, and 5\% in the duodenum [10]. By contrast, NF1related GISTs are located in the small intestine usually in the jejunum and characterized by their tendency for multiplicity [11]. In the present case, the clinical manifestations corresponded to typical NF1-related GISTs.

\section{Conclusion}

Duodenal GISTs are rare neoplasms which may be associated with NF1. The clinician should be aware of this entity in patients with known NF1 disease presenting with gastrointestinal symptoms or intra-abdominal mass.

\section{References}

1. Rasmussen SA, Friedman JM (2000) NF1 gene and neurofibromatosis 1. Am J Epidemiol 151(1): 33-40.

2. Viskochil D (2002) Genetics of neurofibromatosis 1 and the NF1 Gene. J Child Neuro 17(8): 562-570.

3. Yantiss RK, Rosenberg AE, Sarran L, Besmer P, Antonescu CR (2005) Multiple gastrointestinal stromal tumors in type 1 neurofibromatosis: a pathologic and molecular study. Mod Pathol 18(4): 475-484.

4. Riccardi VM (1981) Von Recklinghausen neurofibromatosis. N Engl J Med 305(27): 1617-1627. 
5. Martin GA, Viskochil D, Bollag G, McCabe PC, Crosier WJ, et al. (1990) The GAP-related domain of the neurofibromatosis type 1 gene product interacts with ras p21. Cell 63(4): 843-849.

6. Corless CL, Fletcher JA, Heinrich MC (2004) Biology of gastrointestinal stromal tumors. J Clin Oncol 22(18): 3813-3825.

7. Miettinen M, Fetsch JF, Sobin LH, Lasota J (2006) Gastrointestinal stromal tumors in patients with neurofibromatosis 1: a clinicopathologic and molecular genetic study of 45 cases. Am J Surg Pathol 30(1): 90-96.

8. Takazawa Y, Sakurai S, Sakuma Y, Ikeda T, Yamaguchi J, et al. (2005) Gastrointestinal stromal tumors of neurofibromatosis type 1 (Von Recklinghausen's disease). Am J Surg Pathol 29(6): 755-763.
9. Kinoshita K, Hirota K, Isozaki A, Ohashi T, Nishida Y, et al. (2004) Absence of c-kit gene mutations in gastrointestinal stromal tumors from neurofibromatosis type 1 patients. J Pathol 202(1): 80-85.

10. Miettinen M, Lasota J (2006) Gastrointestinal stromal tumors: pathology and prognosis at different sites. Semin Diagn Pathol 23(2): 70-83.

11. Salvi PF, Lorenzon L, Caterino S, Antolino L, Antonelli MS, et al (2013) Gastrointestinal stromal tumors associated with neurofibromatosis 1: a single centre experience and systematic review of the literature including 252 cases.

\section{Your next submission with JuniperPublishers will reach you the below assets}

- Quality Editorial service

- Swift Peer Review

- Reprints availability

- E-prints Service

- Manuscript Podcast for convenient understanding

- Global attainment for your research

- Manuscript accessibility in different formats

( Pdf, E-pub, Full Text, audio)

- Unceasing customer service

Track the below URL for one-step submission https://juniperpublishers.com/online-submission.php 